\title{
Adaptation of Family Counseling Implementation in School Setting to Meet Student Wellbeing Need: A Qualitative Research
}

\author{
Norhayati Mohd. Noor ${ }^{1}$, Akbariah Mohd Mahdzir ${ }^{2, *}$, Zulkifle Malek ${ }^{3}$, Aidah Abdul Karim ${ }^{1}$ \\ ${ }^{1}$ Faculty of Education, Universiti Kebangsaan Malaysia, 43600 Bangi Selangor, Malaysia \\ ${ }^{2}$ Malaysia Japan International Institute of Technology (MJIIT) University Teknologi Malaysia, Jalan Sultan Yahya Petra (Jalan \\ Semarak), 54100 Kuala Lumpur, Malaysia \\ ${ }^{3}$ Engku Husain Secondary School 43500, Kajang, Selangor Education Ministry of Malaysia, Malaysia
}

Received August 31, 2020; Revised November 30, 2020; Accepted December 8, 2020

\section{Cite This Paper in the following Citation Styles}

(a): [1] Norhayati Mohd. Noor, Akbariah Mohd Mahdzir, Zulkifle Malek, Aidah Abdul Karim, "Adaptation of Family Counseling Implementation in School Setting to Meet Student Wellbeing Need: A Qualitative Research," Universal Journal of Educational Research, Vol. 8, No. 12A, pp. 7792 - 7800, 2020. DOI: 10.13189/ujer.2020.082567.

(b): Norhayati Mohd. Noor, Akbariah Mohd Mahdzir, Zulkifle Malek, Aidah Abdul Karim (2020). Adaptation of Family Counseling Implementation in School Setting to Meet Student Wellbeing Need: A Qualitative Research. Universal Journal of Educational Research, 8(12A), 7792 - 7800. DOI: 10.13189/ujer.2020.082567.

Copyright $\bigcirc 2020$ by authors, all rights reserved. Authors agree that this article remains permanently open access under the terms of the Creative Commons Attribution License 4.0 International License

\begin{abstract}
Western and Asian studies have both proven that family counselling practice in schools has managed to enhance academic achievement, reduce discipline problems, help rectify negative behaviour, decrease learning difficulties of students, and curb absenteeism among students in schools. On the contrary, it has helped boost the potentials and talents of students. Many empirical studies related to counselling teachers' competency in performing family counselling process have been done to support its need, contribution and effectiveness in increasing the wellbeing of students in schools. Thus, the aim of this study, which utilises qualitative approach method with a case study, is to examine the adaptation of family counselling efficient processes, that has become the practice among secondary school counselling teachers to assist students facing problems relating to discipline and academic achievement. In-depth interviews were conducted with six counselling teachers, and the results of these interviews were analysed using Nvivo software. Research findings indicate that counselling teachers had adapted family counselling practical sessions according to their current knowledge level, relying on their experience as well as interest. This adaptation is also influenced by the factors of time constraint, the burden of non-counselling tasks, family commitments, and the limited current knowledge level of counselling teachers. The implications
\end{abstract}

and suggestions have also been discussed in this article

Keywords Family Counselling, Counselling Teacher Competency, School Counselling, Parent

\section{Introduction}

The family counselling process is one of the services offered by school counselling teachers in Malaysia as part of the guidance and counselling service in schools. The provision of family counselling services in schools, as widely documented in other countries, has had a positive effect on the school environment, especially with regard to student development. Many studies have proven that family counselling process is an intervention mechanism that can fortify the institution of the family. Family counselling processes in schools have long been performed in countries such as America, United Kingdom, Canada, Australia and Italy; they have reduced conflict between school children and parents (Kindsvatter et al. 2008). Studies in Thailand done by Pinyuchon (1997) and Kim (1985) in Hong Kong have demonstrated that family counselling conducted in school settings have succeeded in helping students return their focus to the learning 
process.

Studies relating to family psychology and counselling have highlighted that the family is responsible for the majority of troubled children. In a study conducted in Mexico, a group of researchers in Mexico did a collaborative study with school counsellors and medical centres, conducting a family counselling process involving students from primary schoolchildren. Research findings indicated that the counselling process that was used as the intervention program managed to reduce violent incidents, truancy, and increased overall satisfaction of teachers and parents with students within the learning environment of schools (Mearns 1999, Carr, 2019). Truancy directly affects the student by impeding their academic growth and has also been linked with delinquency and high school dropout (Leo Nguyen, 2020).

The findings of Graves (2009), meanwhile states that family counselling is more effective in assisting children experiencing emotional distress, compared to individual counselling. He stresses that in cases of children who are given a high level of individual counselling, there seem to be no substantial benefits in reducing the emotional distress that they experienced. Research by Etgar (2009) in Israel depicts that the problem of youths involved in sexual misconduct can be addressed with a combination of individual and family counselling intervention. These findings also show that this combination model of counselling is more effective and works faster to help remedy the problem of sex addiction faced by adolescents in school. Hence, there are much experimental research and case studies conducted overseas that show that the family counselling process has a high efficacy rate in handling family problems (Carr 2009; Coco \& Courtney 1998; Robbins \& Szapocznik 2000).

According to Zainal Abidin and Zamre (2006), changes in the family involving norms, family organisation, values, worldview, family function, interaction and communication within the family, and role of family members, all have an impact on the family institution. In Malaysia, a great deal of family counselling research in the community counselling service environment has been done by Saedah (2004), Norhayati (2012) and Rusni (2013), which centred on the way family counselling processes were carried out and also on its effectiveness in enhancing harmony in the family. However, to date, discussion and literature relating to family counselling practices in school have been limited to conceptual writings (Zuraimey, Mohd. Najib \& Mohamed Sharif, 2008 ), and in counselling books that have been written by academicians in Malaysia. It should be noted that, relative to individual counselling, group counselling and career counselling, the introduction of family counselling activity and practices in Malaysian schools still lag far behind. This lag is due to limited studies focusing on family counselling processes for practical implementation among counselling teachers in secondary schools in
Malaysia. Although many studies have shown that a family counselling process is an intervention tool that can improve the family structure, there are limited research looking into this in Malaysia. Therefore, there is an urgent need to explore and understand this phenomenon. In order to discover a useful implementation model that can be implemented, suitable for the needs and unique situation of students, this study hopes to examine and recognise the implementation practises of family counselling through counselling teachers in secondary schools.

\section{Implementation of Family Counseling in Schools}

To date, problems relating to the violation of rules, involvement in social ills, academic dropping out, truancy and non-attendance in schools have reached critical levels. Statistics given by the Women, Family and Society Ministry in 2015 show that 4,569 youths were arrested due to involvement in juvenile cases. According to Nurzatil Ismah et al. (2015), social problems in the state of Selangor have risen annually, and the highest number of cases of social problems in Malaysia has been registered.

School authorities have undertaken various efforts to resolve the issue of negative conduct encountered by students in schools. Research conducted in Malaysia by Saedah (2004), who conducted family counselling studies, found that family counselling processes can support children with problems. She performed research on family counselling processes to study the efficacy of family counselling, relative to individual counselling, in order to improve family resilience, family harmony, and the general family atmosphere, in order to address the behavioural and self-image problems of troubled young adolescents. Her research results indicate that in contrast to the individual counselling process, family counselling processes may help young people modify behaviour patterns. This study is also backed by studies by Norhayati (2012) and Rusni (2013). Thus the method of family counselling not only allows children to alter maladaptive behaviour, but can also curb the rise of school discipline issues.

Consequently, as numerous studies have shown its effectiveness, it is fitting that the introduction of the family counselling process in schools should become the key agenda for counselling teachers in secondary schools in Malaysia. School counsellors must have the requisite knowledge of necessary concepts, family systems and techniques, according to Keith (2012), in order to be able to administer counselling sessions more effectively involving students, school and family. If school counsellors use family system application and conduct school counselling programs, including educational programmes, training and supervision of school counsellors within this paradigm scheme, the method adopted by school authorities and trained school 
counsellors will improve competency. However the primacy of school counsellors for the mental health of students and their families is not perceived by most schools. Due to the burden of tasks, which are not related to their counselling work, school counsellors accord little attention to making preparations for programs that enhance their professional capacities (Warren, Jones, \& Unger, 2020). Owing to increased administrative responsibilities, exacerbated by the emergence of complex, threatening issues affecting the school environment, students and parents, the duties of counsellors in schools are often growing (Jane Dally, 2013).

In Malaysia, the family counselling model in schools that can be a reference for counsellors is not given sufficient prominence or addressed scientifically. Widmayer E. has proposed the model of family counselling and consultation in 1967. This model was subsequently developed further by Nicoll (1992), who intensively propounded the model of family counselling and consultation that needed to be implemented by counselling teachers in schools. Nicoll (1992) recommended that counsellors in schools conduct a dynamic assessment of the family system by helping those students experiencing behavioural issues and learning difficulties. The role and duties of the counsellor who is continuously engaged with students, families and class teachers would provide extensive opportunities to conduct family counselling and consultative processes. Nicoll was of the view that the existing family therapy model was not suitable for the requirements of students in schools. In his article, he put forward eight steps that could be performed by counsellors in school involving family consultation and counselling. The steps that could be carried out by counselling teachers are: i) Stabilising the situation, ii) Description of problems in school, iii) Study of siblings and parents' lifestyle, iv) Description of problems at home, iv) Reformatting or relabeling all problems, v) Suggestions of school, vi) Suggestions of home, and vii) Concluding session and follow-up schedule. Hence, this study intended to explore adaptation in the implementation of family counselling practices performed by counselling teachers in secondary schools in the handling of student cases that are linked to the family.

\section{Methodology}

This study was conducted to examine the family counselling processes that have become the practice of counselling teachers in secondary schools utilising the qualitative approach with case study design. The selection of this case study design enabled the researchers to examine the phenomenon of family counselling practices( Creswell 2014). This study also sought to fill the gap in the literature by developing a deeper understanding of implementation and challenges of the practice of family counselling in the school setting in Malaysia.

Research participants selected for this study were counselling teachers who had served more than five years and possessed registration license and certification of practice from the Malaysian Board of Counsellors. The selection was based on experience, education and training, and professional recognition (Bowen \& Caron, 2016). A total of six counselling teachers participated in this research. The selected research participants were counselling teachers who were identified as having served at least five years in schools and had counselling license from the Malaysian Board of Counsellors. Researchers had applied for permission from the Education Ministry of Malaysia, and research was done for one year. The interview protocol was modified from the original research protocol that was conducted for family counselling practices in community settings (PhD research). Researchers utilised the services of two Master candidate students in counselling for the preparation of interview transcripts. They re-examined the transcripts to ensure accuracy of the lexicon of research participants. This process was done to avoid errors during data analysis.

Research data that had been transcribed was analysed using NVivo 12. Researchers analysed utilising both inductive and deductive methods based on literature that had been studied, theories, models suggested by other researchers, and also based on the own experiences of the researchers in family counselling process in schools.

\section{Findings}

After the interview data had been transcribed and analysed, the themes that emerged from the adaptation of family counselling in schools were: i) family consultation, and ii) family counselling process. The family consultation process occurred in two situations, namely: i) occurring at home, and ii) occurring at school.

\section{Practices of Family Consultation Implementation and Family Counseling Process}

Based on these research results, the practice of the family counselling method at the secondary school level has established two primary practises that include the process of family consultation and the process of family counselling. These are both tasks that are the core practises of counselling teacher in helping them to manage students' cases involving school disciplinary and academic issues. Research results also indicate that when the counselling teacher handles student cases linked to the family, the consultation process and counselling process occur interchangeably in schools. Both of these procedures are also the approaches used for teacher 
counsellors after the individual counselling process has failed to have a significant effect on students.

\section{Family Consultation at Home}

Family consultation is more frequent in schools compared to family counselling as family consultation is more relaxed and does not require a lengthy period in its implementation. Consultation and counselling processes also occur at students' homes when there are student cases that require the counselling teacher to go to the students' homes to assist. According to Counseling Teacher 1 (CT1), the teacher goes to the home to carry out consultation process, and family counselling when the student no longer wants to attend school and the parents are incapable of taking any action. This situation causes the counselling teacher to have no other choice; and to render help to the student, the counselling teacher makes a visit to the home, and at the same time, consultation process and family counselling would then be carried out.

Visiting the house, the student's mother came and said the child indeed has problems, like playing truant, but while at primary school, they gave so much pressure to the child that he/she is now stressed up.

(In-depth Interview/CT 1)

Visiting homes has become a strategy for all counselling teachers in this study. The strategy of visiting students' homes seems to have become something that is agreed upon by all counselling teachers as the best way, and is quite useful in solving the problems of students facing discipline and academic problems say CT6. Their experience, utilising the strategy of visiting the students' homes, enables the teachers to have a greater understanding of the students' problems. According to CT2, when the visit was made to one student's home due to absenteeism, the teacher could see personally the student's mother lying bed-ridden, and indirectly, this was one of the contributing factors for the student not attending school.

However, if there is time, I strongly feel that visits to homes is really very effective.

(In-depth Interview/CT6)

Then I visited the house, and in fact the mother was lying down, unable to get up, and while I was there, not a single person came to visit.

(In-depth Interview/CT2)

According to the counselling teachers, visits to homes can help them to handle student cases where their parents do not commit to making them attend school. There are also cases where parents ask the counselling teachers to persuade their children who have given up hope and are demotivated, to continue with their studies. In line with the principle of providing help to the maximum level possible, visiting homes is a strategy that could save the future of the child, who for the most part, has problems that are non-school related, according to CT3. However, there are cases where the visiting counselling teacher encounters a negative reaction from parents. According to the experiences of one of the counselling teachers, CT2, there is a segment of parents who resent the efforts of the counselling teacher to help the student resume their education process. For these parents, the function of the teacher is only within the school, and they do not have to visit students' homes.

If there are cases where they really do not come ... when talking about home visits, there was another case where we wanted to help, they came, but after that, the parent came to ask for help, he came just like that ....Because of him, the process of absenteeism we will just throw out, because our step, our session, has finished, then we will go and visit the home.

(Indept Interview/CT2)

I have experienced one case of absenteeism in school... So went to look for the child at the home, because the parents requested us to help them.., as we know that if absenteeism goes onfor very long the student will be expelled...So the first step in a counselling session will be done, but if the student is still not coming, then we will visit the house-

(In-depth Interview/CT3)

Counselling teachers in school mostly do the family consultation process. All research participants have stated that the family consultation process is the more effective process, and it is speedier in handling student problems that are strictly related to disciplinary problems and academic issues. The consultative process is usually used as a method in helping resolve student discipline problems. Collaborative consultation that involves the Senior Assistant teacher, along with the parents, can enhance effectiveness.

So, I called her mother, but I did not tell her about this case, I only said okay, the school has a little discipline problem and asked her to come. And then she came, and the afternoon PK (Senior Assistant) and I told her about how the case was.

(In-depth Interview/CT1)

Therefore, the family consultation process is carried out more by the counselling teacher in secondary schools in the handling of student issues that are related to the family. This shorter process, which does not require a lengthy period, has made counselling teachers favour using the consultation process due to their time constraints and also due to the high commitment required for parents to come to the school. The strategy of visiting homes also has facilitated the consultation process and made its implementation more effective. 


\section{Family Counseling Process Implementation Practices}

Family counselling process practices among counselling teachers, which was highlighted through interviews, noted similarities and differences between one another. The similarities and differences highlighted were due to the processes carried out by counselling teachers and referred to student cases that were handled by counselling teachers. The process of family counselling sessions performed for disciplinary and academic cases called for different procedures and was influenced by parents and students. Parents and students who are able to be committed, and continuously give cooperation can hasten the process and do it with quicker measures. So, in this study, counselling teachers find it difficult to specify the duration of the process, the levels of each session, the approach utilised and the precise process that is adopted.

If parents come, it is easier to help, if they are serious cases, we do need the parents' presence, it makes our job easier, meaning the cooperation of the parents is exceptionally vital to settle these issues. If the client comes willingly, these issues can be resolved. However, we do need to give these issues the needed cooperation.

(In-depth Interview/CT2)

Overall, at the preliminary stages of the sessions for discipline cases, the same procedures are used, namely using the telephone to contact the parents, asking them to come to school to resolve the discipline issues of the student, with the knowledge of the parents. Counseling Teacher 1 and Counseling Teacher 2 clarified that they always used the telephone to contact parents when they needed to settle cases of a disciplinary nature, and that related to the family.

So, I called the father and found out what actually had transpired; the student's step-mother had beaten him. I asked the father to come, but he brought the step-mother and step-sister along.

(In-depth Interview/CT1)

The usage of the telephone at this stage, according to counseling Teacher 4 and Counseling Teacher 3is an easy and effective procedure, be it for discipline cases or academic cases. Also, parents give feedback more quickly regarding their appointments in schools, and this speeds up the family consultation and counselling process conducted by the counselling teacher. The procedure of using the telephone is also useful for follow-up processes, in order to find out the progress of the client and the family after the first session is completed. This means that the consultation and counselling process is effectively able to be accomplished by means of using the telephone.

Parents also agree with students when we call parents, and parents would agree to be present.

(In-depth Interview/CT3)

Finally, we would telephone the parents back and we would tell them about their child's situation ...

(In-depth Interview/CT4)

In this study, the middle part of the family counselling process session has not been specified clearly by the counselling teachers. The lack of clarity in this stage was due to the fact that the students' cases were unique, and there was a high level of diversity. Family counselling process often happens only after several individual counselling sessions between the student and counselling teacher, and it is only after these sessions that counselling sessions together with the parents take place. Besides that, family counselling frequently happens simultaneously with family consultation sessions. In this study, the experience of CT1 in the mid-section of the counselling process happened only after the counselling session with the student. The joint session with the student's mother took place in the form of consultation, considering that the consultation process is needed to provide understanding to the student's mother in helping to bring about positive changes in the student's behaviour.

Okay, after some time, I called the mother but it was kind of difficult to understand her as she spoke in a nasal tone; nowadays we cannot speak to students too angrily, we need to control a little, speak softly, if we speak to them in an angry way, they do not accept it, right? I can use the analogy of throwing a ball, the harder we throw a ball to a wall, the harder it bounces back to us. It is we who will be affected badly. But if we throw the ball slowly, we can catch the ball that bounces back. This is how I speak to the student, I just hope they understand.

(In-depth Interview/CT1)

The ending part of the session is portrayed as a unique stage and does not happen as depicted scientifically. All counselling teachers have stated that the ending stage is challenging to explain clearly and accurately. For counselling teachers, student cases that have been resolved are a challenge as far as documentation is concerned, due to the fact that it involves the parents, the varying scenario of each case, and the factor of time constraints of the counselling teachers. According to the counselling teachers, there are times when students' cases have a positive outcome, but there are cases where it needs to be handed over to another party, especially when it demands expertise that is beyond their scope.

Yes, because we know, in my experience when I handle families, there are a great many steps that we need to help with, and we have to show them how to perform them.

(In-depth Interview/CT4)

The mother called me and was crying when she saw me because I felt the child had to be referred to a psychiatrist/psychologist. Because the student was unable to accept school, so she was unable to accept reality. They avoided the whole situation and just 
wanted to stay away completely from school. I had a referral letter but she did not want to go ...

(In-depth Interview/CT5)

Due to this, family counselling process practices by the counselling teacher tends to lean more towards consultation, as opposed to the family counselling process. The factors of time constraints of the counselling teachers, competency of counselling teachers, and support of the parents have all influenced the practice of family consultation and counselling processes that are handled by counselling teachers in school. Family consultation and counselling processes are also conducted in students' homes when there are cases where students refuse to attend school, but still, allow counselling teachers to help the student.

\section{Discussion, Implications of Study and Suggestions}

This research was conducted to understand the school counselling teachers did the needs of implementing family counseling in schools with the objective of enhancing the wellbeing of students in schools and this adaptation. The rationale of the need to implement family counselling in schools is crucial to focus on the development of positive behavioural patterns, particularly among secondary school students who face distress due to family factors. It is noteworthy that this study found that the consultative process was more frequently conducted, compared to the family counselling process.

Family counselling processes carried out by counselling teachers also involved individual counselling processes. Combination processes of individual counselling took place as well, based on the cases received by counselling teachers, especially involving both academic and discipline aspects of the student. All counselling teachers in this study did not use any family counselling model in the school setting. Therefore, they prefer to use the method in their way. In this study shows that no teacher implemented the model presented by Widmayer E. in 1967 and Nicoll W. G (1992).

According to Warren J. M., Jones S. J., Unger D. L., 2020, barriers exist, that prevent school counsellors from effectively delivering comprehensive school counselling services that meet the needs of all students. Studies by Etgar T. \& Shulstain-Elrom H. 2009, showed that family counselling processes that were combined with individual counselling were capable of providing positive effects on students experiencing problems such as sexual misconduct. However, this study found that in sexual cases in schools, it was not suitable to use the combination of individual and family counselling, following research done by Etgar T. \& Shulstain-Elrom H. (2009). Sexual cases in Malaysia school must involve another party, such as government agencies responsible for the implementation of child violence laws and child protection acts.

Findings also attest that family counselling is more useful to aid children who are experiencing emotional upheavals, compared to individual counselling. Financial problems, divorce, parents being pre-occupied with work, and unhealthy living environment are among the main factors that cause emotional disturbance among the youngsters (Carr, 2019). Baker (2011) declares that lack of financial support, too little time spent with parents at home, failure by parents to monitor and discipline children in a consistent manner, and inadequate control over activities and interaction with the peer group, have been proven to be contributing factors for negative behaviour. Therefore, if student cases are dealt with primarily by individual counselling, it would have minimal impact, especially when dealing with experiences of emotional turmoil (Graves,2009). As such, development of positive emotions, especially of students in secondary schools, is critical, as this positively impacts academic and psycho-social attainment (Williams 2014).

The relationship between family structure and disciplined conduct is very much interconnected (Baker, 2011). Involvement in family counselling processes has demonstrated that the mother/ wife displays better commitment compared to the father/ husband as the mother usually has more flexibility with time when they are full-time housewives, which enables them to attend family counselling sessions in schools. At the same time, fathers or husbands are busier with career or work in order to support the family financially. Other than that, both parents' presence is at a low level, where only one parent, either the mother or father, would show up for the sessions. Since parents were unable to attend the family counselling process at school, adaptation to the family consultation procedure was carried out. Hence, counselling teachers visit students' houses in their effort to provide family counselling consultation.

As mentioned earlier, counselling teachers at school have added value to the family counselling process with the adaptation in the procedure whereby house visits were conducted in cases where students were expelled from school, or when parents are unable to commit in sending their kids to school. It is also to be noted that there is a segment of parents who do not cooperate to assist in overcoming students' problems in school, such as by transferring their children to other schools if they are involved in serious offences. On the other hand, school counsellors have decided to make visits to clients' homes to see for themselves the condition of the client and the family. The school counsellor does this as there are several constraints faced by the client; namely, the parents having financial hardship and not possessing vehicle, parents not cooperating in attending sessions in school, and the students themselves not showing up in school. Therefore, if counselling teachers agree to go to the students' homes, they need to be equipped with sound 
knowledge, skills, and mutual support in order to ensure that their services may be performed in an efficient and meaningful manner (Bowen and Caron, 2016).

Other than that, family counselling also exerts a substantial influence and plays a vital role in the resolution of problems of students in school, when the problem stems from their own homes (Stein, 1985). Research findings point out the effectiveness of family counselling sessions in schools, which help students and their families to overcome the problems of poor attendance, truancy and loitering, promiscuous sexual behaviour, abuse by step-parents and poor academic performance. Family counselling also can bring about behavioural changes to clients, be it the students themselves, or their parents, wherein both parties can re-establish harmonious relationship after undergoing many years of crisis between them. Multiple techniques and approaches have been utilised by these counselling teachers, including the provision of consultation services for parents as this parents-teachers collaboration will have a positive impact on the overall counselling session effectiveness conducted on students. The findings of this research showed that the novel approach in encouraging the collaboration between counselling teachers and parents succeeded in increasing the level of happiness amongst students.

Counselling teachers are faced with time constraints in carrying out family counselling processes at school. They encounter the burden of non-counselling work, for instance, relief classes, escorting students to non-counselling events, preparing files related to school recognition, among others. Due to these non-counselling tasks, counselling teachers find themselves deprived of time to focus on their counselling work. School administrators, such as headmasters who do do not fully appreciate the benefits of implementing counselling programs, and the vital role that they play in schools, further add to the limitations imposed on counselling teachers in carrying out family counselling processes in schools (Nelson et al., 2008). These issues mostly are resolved through innovations in preparation. Policy development and implementation are the fundamental driver of preparation, professional identity, student outcomes, and future policy development (Warren, Jones, Unger, 2020)

It is highly appropriate that the implementation of family counselling in Malaysian schools be bolstered among counselling teachers in order to address the misbehaviour issue of students that is increasingly becoming more critical. Much research have been done in many countries that have proven that family counselling is a useful intervention tool in helping solve the problems of students at school, particularly those problems that relate to and arise, out of family conditions (Carr, 2019; Haliburn, 2017; Patterson, Edwards \& Vakili, 2018). Indeed, many psychological studies have also proven that children of various age groups excel in terms of self-performance, academics and positive behaviour traits when there is harmony in the family.

\section{Limitations}

This study was done qualitatively as it intended to provide researchers with the opportunity to explore the phenomenon of counselling process implementation by counselling teachers in secondary schools. The limitations of this study are that the in-depth data was procured, utilising interviews with only six counselling teachers. Difficulties in securing a voluntary and high level of participation from counselling teachers did pose a challenge. Counselling teachers in Malaysia do not work according to regular office hours; they only work during the duration of school hours, which is about six hours. Thus, interview sessions were only able to be performed for about 30 to 45 minutes. The observation was not able to be done as observation sessions were cancelled due to the changing schedules of the counselling teachers, who were confronted with demands from non-counselling tasks.

In this study, it was found that some counselling teachers had only superficial knowledge of family consultation and counselling. Counselling teachers' knowledge of consultation with parents was only obtained at Bachelor degree level, and even then, not all of them studied it as some universities did not offer the subject of Parent Counseling. The knowledge of family counselling process was only obtained at Bachelor degree level (one subject) and Master level (one subject). Hence the shallow knowledge of these counselling teachers only permitted them to perform according to their limited knowledge level.

Not even one of the counselling teachers in this study had specialised training of family counselling at the Master level. Family counselling conducted by them was primarily based on experience gained over their years of service and not utilising attending workshops or seminars. Moreover, almost none of these counselling teachers had directly witnessed how a proper family counselling session is conducted.

\section{Implications}

This study has given a more in-depth insight into the current state of family counselling in schools

Home family consultation seeks to support low-income families who lack access and are unable to afford the time and resources to participate in the school counselling process. Since parents are unable to participate in the therapy process due to financial and time constrain, this process can be done more effectively and efficiently at home as an alternative solution to the failure of parents to 
attend the school counselling session. Students within this income category can then be supported, and the issue of absenteeism can be minimised.

Family counselling process, that entails deep engagement of all stakeholders including students, parents, and teachers, would be able to enable both parents and teaches to manage these students in order to solve the issue of absenteeism. Counsellors are equipped with more in-depth knowledge to strategically counsel parents to assist their children.

Counselling teachers in schools perform more family consultation processes rather than family counselling. Time constraints (due to non-counselling tasks), coupled with a lack of knowledge and skills in performing family counselling, has impaired their ability to perform family counselling processes even though they do realise its effectiveness. Based on this research, teachers have a better understanding of the efficacy of the approach of family therapy in handling the issue of absenteeism among these students. Their continuous engagement with students, families and other teachers would provide extensive opportunities for them to conduct family counselling and consultative processes.

The effectiveness of family counselling as an intervention measure in resolving students' issues arising from the family has been acknowledged and accepted by counselling teachers. Snyder M.S. (2010) has stated that training in identifying family counselling process has to be provided for teachers so that they can make referrals of students who need family counselling services. In this regard, support in the form of training, and reducing their non-counselling workloads, needs to be accorded due attention in order to realise the full potential of family counselling processes in the school.

\section{Conclusions}

The family counselling service, the practise of counselling teachers in Malaysia, has not been successfully implemented, although it is urgently required to optimise student growth. The drastic upsurge in students with family-related issues caused by the rise in parental divorce rates, the increase in living costs, and the competition of higher academic grades have all led to increased student stress levels. Therefore, family therapy counselling service carried out by counselling teachers has a tremendous capacity to serve as an appropriate intervention measure to assist students. If counselling teachers could play a more meaningful and productive role in the family counselling process in Malaysian schools, various disciplinary problems such as missing classes, truancy, sleeping in class, gangsterism and other such maladies could be curtailed. Additionally, students who are struggling due to weak academic performance would be significantly assisted using family counselling processes.

\section{Acknowledgements}

This study was supported by a grant from Faculty of Ecucation Universiti Kebangsaan Malaysia Research Grant Scheme (GG-2019-053).

\section{REFERENCES}

[1] Baker T.C. (2011). Impact Of Family Structure On The Academic Achievement And Behavior Of High School Students. Presented in Partial Fulfillment of the Requirement for the Degree Doctor of Education in the Graduate School of Texas Southern University

[2] Bowen J.M. \& Caron S.L. (2016). A Qualitative Analysis of Home-Based Counselors' Experiences in a Rural Setting. Journal of Counseling \& Development.Volume, 94.

[3] Carr ${ }^{\mathrm{a}}$, A. (2009). The effectiveness of family therapy and systemic interventions for child focused problems. The Association for Family Therapy. Journal of Famliy Therapy 31: 3- 45 .

[4] Carr ${ }^{b}$ A. (2009). The effectiveness of family therapy and systemic interventions for adult-focused problems. The Association for Family Therapy. Journal of Famliy Therapy 31: 46-74.

[5] Carr, A. (2019). Family therapy and systemic Interventions for child-focused problems: the current Evidence base. Journal of Famliy Therapy 41: 153- 213.

[6] Coco, E.L. \& Courtney, L.J . (1998). A family systems approach for preventing adolescent runaway behavior. Adolescence, Vol. 33, Issue 130

[7] Creswell, J. W. (2014). Educational research: Planning, conducting, and evaluating quantitative and qualitative research (forth ed.). New Jersey: Person Merril Prentice Hall.

[8] Davis KM., Lambie G.W. \& Kara P. Leva K.P. (2012). Influence of Familial Spirituality: Implications for School Counseling Professionals. American Counseling Association.

[9] Etgar T. \& Shulstain-Elrom H. (2009). A Combined Therapy Model (Individual and Family) for Children With Sexual Behavior Problems. International Journal of Offender Therapy and Comparative Criminology, Volume 53, Number 5.

[10] Gibson D. M. et al. (2012). From Counselor-In- Training to Professional School Counselor: Understanding Professional Identity Development. Journal Of Professional Counseling:Practice, Theory, And Research, Vol. 39, No. 1.

[11] Graves, K.N. et al. (2009). Utilisation of Individual versus Family Therapy Among Adolescents with Severe Emotional Disturbance. The AmericanJournal of Family Therapy, 37:227-238.

[12] Jane Dally. (2013). A Case for Mental Health Competency 
in School Counselors. Submitted in Partial fulfillment of the requirements for the degree of Master of Arts from Prescott College In Education: School Guidance Counseling

[13] Kim S.C. (1985). Family Therapy For Asian Americans: A Strategic structural Framework. Psychotherapy Volume 22. Number $2 \mathrm{~S}$

[14] Kindsvatter A., Duba J.D. \& Erin P. Dean E.P. (2008). Structural Techniques for Engaging Reluctant Parents in Counseling. The Family Journal, 6: 204.

[15] Kraus, Inez. (1998). A fresh look at school Counseling: A family-systems approach. Professional School Counseling, 10962409, Vol. 1, Issue 4.

[16] Leo Nguyen . (2010). A School-Based Truancy intervention: A Grant Proposal.

[17] Merriam, S.B. (2014). Qualitative Research : A Guide to Design and Implementation Jossey-Bass A Wiley Imprint

[18] Mearns, C, (1999). Brief family Counseling Interventuon Cibola Cluster. Research, Development and Accountability. Report- Evaluative (142).

[19] Judith A. Nelson J.A, Robles-Pina R. \& Nichter M. (2008). An Analysis of Texas High School Counselors' Roles: Actual and Preferred Counseling Activities. Journal of Professional Counseling: Practice, Theory and Research Vol. 36,

[20] Nicoll, William G. (1992). A family Counseling and Consultation model for school Counselors. School Counselor. 00366536, Vol. 39, Issue 5.

[21] Norhayati Mohd Noor. (2012). Proses Kaunseling Keluarga dalam kalangan pengamal Kaunseling Keluarga di Malaysia. Tesis PhD. Tidak diterbitkan. Fakulti Pendidikan. UKM

[22] [22] Nurzatil Ismah binti Azizan et al. (2015). Permasalahan Sosial Dalam Kalangan Remaja Di Selangor: Satu Tinjauan. Seminar Antarabangsa Akidah, Dakwah Dan Syariah 2015) (IRSYAD2015), Kuala Lumpur,

[23] Perera-Diltz D. M., Moe J.L \& Mason K.L. ( 2011). An Exploratory Study in School Counselor Consultation Engagement.

[24] Pinyuchon, M. \& Gray, L.A. (1997). Understanding Thai Families: A Cultural Context for therapists Using A Structural Approach. Comtemporary Family Therapy 19(2):209-228

[25] Robbin, M.S. \& Szapocznik, J. (2000). Brief Strategic Famiy Tharapy. Juvenile Justice Bulletin. Pg 1-11.

[26] Rosni A. Ghani. (2013). Keberkesanan Intervensi Keluarga dalam merawat tingkahlaku delinkuen persalah remaja Tesis Dr fal., Fakulti Sains Sosial, Kemanusia, Universiti Kebangsaan Malaysia

[27] Saedah A. Ghani. (2004). Kesan kaunseling keluarga ke atas penyesuaian keluarga kohesi keluarga, persekitaran keluarga , tingkahlaku bermasalah dan konsep kendiri remaja Tesis PhD.Tidak diterbitkan (unplished). Fakulti Sains Sosial \& Kemanusiaan. UKM

[28] Snyder M.S. (2010). Teachers' Perceptions Of Students' Needs For Family Counseling and Attitudes Toward School-Based Family Counseling. A Dissertation Presented in Partial Fulfillment Of the Requirements for the Degree Doctor of Philosophy Capella University.

[29] Stein, S.J. et al.(1998). The kindship of Adlerian family counseling and Minuchin's structural family therapy. The Journal of Individual psychology 4(1):90-107.

[30] Warren J. M., Jones S. J., Unger D. L. (2020). Strengthening Professional School Counseling: A Call to Action. Professional Issues in Counseling, Volume VI, Article 1, pp. 61-76

[31] Widmayer E. (1967). School Counseling and Family Consultation. The National Catholic Guidance Confrence Journal. Volume 11, Issue 4. Pages 209- 258.

[32] Williams L.S. (2014). The Relationship Of Family Structure, Parental Involvement, School Activities, And Counseling On The Academic Achievement Of African American Girls A Dissertation Presented in Partial Fulfillment Of the Requirements for the Degree Doctor of Philosophy Capella University.

[33] Windle M. H.(2009). Counseling Matters: A Multi- Case Study of High School Counselors And Their Perceptions of Their Role in the School Community. A dissertation submitted to the Graduate Faculty of North Carolina State University in partial fulfillment of the requirements for the degree of Doctor of Education

[34] Yin, K. R. (2014). Case study research- design and methods (ed. Ke 2). Thousand Oks: Sage Publications International Educational and Professional Published

[35] Zainal Abidin Borhan \& Zamree Abu Hassan. (2006). Nilai keluarga melayu dan cabarannya dalam pembangunan (hal. 10-24).- Institut keluarga menghadapi cabaran alaf baru. Suntingan Abd. Rahim Abd. Rashid, Sufean Hussin \& Jamaludin Tubah Utusan Publication \& Distributors Sdn Bhd.

[36] Zuraimey Ahmad, Mohd Najib Sapari \& Mohamed Sharif Mustaffa. (2008). Amalan serta Peranan dan Tanggungjawab Kaunselor di sekolah-sekolah dalam menangani masalah kekeluargaan 